\title{
Türkçeyi Yabancı Dil Olarak Öğrenenlerin C1 Yazma Sınavındaki Dil Bilgisi Hatalarının Düzeylere Göre Dağılımı
}

\author{
Latif İtar* \\ Makale Geliş Tarihi: 28/12/2020 \\ Makale Kabul Tarihi: 27/01/2021 \\ DOI: $10.35675 /$ befdergi. 848590
}

$\ddot{O} z$

Yabancı dil olarak Türkçe ögrrenenlerin C1 sinavı yazma becerisinde yapmış oldukları dil bilgisi hatalarını seviyelere göre tespit etmeyi amaçlayan bu çalışmada nitel araştırma desenlerinden durum (örnek olay) çalışması kullanılmıştır. Çalışmada doküman incelemesine başvurulmuş olup verilerin analiz edilmesinde içerik analizinden yararlanılmıştır. Araştırmanın verilerini 2018-2019 akademik yılında Ankara Yıldırım Beyazıt Üniversitesi Dil Ĕ̈itimi Uygulama ve Araştırma Merkezinde öğrenim gören 43 öğrencinin C1 yazma sınavına vermiş oldukları cevaplar oluşturmaktadır. Dil bilgisi konularının seviyelendirilmesinde çalışma grubundaki öğrencilerin Türkçe öğrenimi süresince kullanmış oldukları Yedi İklim Türkçe Öğretim Seti'nde belirtilen dil bilgisi kuralları esas alınmıştır. Çalışmanın sonucunda dil bilgisi hatalarını \%80'inin A1 seviyesinde, \%4,7'sinin A2 seviyesinde, \%13'ünün B1 seviyesinde ve \%1,5'inin B2 seviyesinde olduğu tespit edilmiştir. Hata olarak en slk tekrar eden beş dil bilgisi yapısının \%20,7 ile belirtme hâli eki, \%16,4 ile isim tamlaması, \%13 ile büyük ünlü иуuтu, \%8,2 ile yönelme hâli eki ve \%4,5 ile çokluk eki olduğu sonucuna ulaşılmıştır.

Anahtar Kelimeler: Dil bilgisi, Türkçe C1 sınavı, yazma becerisi, yazma hataları

\section{Distribution of Grammar Errors in C1 Writing Exam in accordance with the Levels of Students who Study Turkish as a Foreign Language}

\begin{abstract}
In this study, which aims at determining the grammar mistakes made by those who learn Turkish as a foreign language in the Cl exam, in the writing skill part, in accordance with their levels, a case study from qualitative research design patterns was employed. Document review was implemented in this study, and content analysis was used to analyze the data. The data of the study consists of the answers given in the C1 writing exam submitted by 43 students studying at Ankara Ylldirlm Beyazlt University, Language Education Application and Research Center in the 2018-2019 academic year. As a result of the study, it was determined that $80 \%$ of grammar mistakes are at Al level, $4.7 \%$ at A2 level, $13 \%$ at B1 level and $1.5 \%$ at $B 2$ level, respectively.
\end{abstract}

Keywords: Grammar, Turkish Cl exam, teaching Turkish as a foreign language, writing skill, writing errors

\section{Giriş}

Dil öğrenim süreci içerisinde ihtiyaç duyulan seviyeler, Diller İçin Avrupa Ortak Öneriler Çerçevesi'nde altı geniş basamak olarak belirlenmiştir. Geleneksek *Yıldırım Beyazıt Üniversitesi, Ankara, Türkiye, liltar@ybu.edu.tr, ORCID: 0000-0002-2807-8083 (D)

Kaynak Gösterme: İltar, L. (2021). Türkçeyi yabancı dil olarak öğrenenlerin c1 yazma sınavındaki dil bilgisi hatalarının düzeylere göre dağılımı. Bayburt Ĕ̆itim Fakültesi Dergisi, 16(Özel Sayı), 129-147. https://doi.org/10.35675/befdergi.848590 
sınıflandırmayı içeren ve üç büyük öneri düzeyi olan temel, orta ve üst seviyelerden yola çıkarak yeni bir sınıflandırma yapılmıştır. Bu sınıflandırmaya göre düzeyler; temel dil kullanımı (A), bağımsız dil kullanımı (B) ve yetkin dil kullanımı (C) olarak ifade edilmiş ve kendi içerisinde A1, A2, B1, B2, C1 ve C2 olarak alt1 alt düzeye ayrılmıştır (Avrupa Konseyi/Modern Diller Bölümü [AK/MDB], 2013, s. 29-30). Türk üniversitelerinin öğretim dili Türkçe olan programlarında yabancı uyruklu öğrencilerin öğrenim görmeye başlayabilmeleri için üniversitelerin büyük çoğunluğu tarafından $\mathrm{C} 1$ düzeyinde Türkçe belgesi şart koşulmaktadır. Yurtdışı Türkler ve Akraba Topluluklar Başkanlığı tarafindan yürütülen ve her yıl binlerce yabancı uyruklu öğrencinin Türk üniversitelerinde öğrenim görmeleri amaciyla burslandırılmalarını sağlayan Türkiye Bursları Programı'nda öğretim diline bakılmaksızın tüm öğrencilerin burslandırıldıkları programlarda öğrenim görmeye başlayabilmeleri için $\mathrm{C} 1$ düzeyinde Türkçe belgelerini ibraz etmeleri şart koşulmaktadır. $\mathrm{Bu}$ anlamda yabancı dil olarak Türkçe öğretim faaliyeti yürüten merkezlerin ve kursların büyük çoğunluğunun öncelikli çalışma alanı öğrencilerini C1 düzeyinde Türkçe sınavlarına hazırlamak olmaktadır.

Yabancı dil öğretimi, süreç temelli bir öğretimi esas almaktadır. İstenilen seviyeye ulaşılabilmesi için süreç içerisinde geri dönütler alınır ve bu geri dönütler neticesinde ilerlemeler yapılır. Öğrenilenlerin unutulmasının önüne geçmek ve öğrenilenleri pekiştirmek amacıyla öğretim programları içerisinde daha önceki öğrenmelere yer verilir. Bu anlamda yabancı dil öğretim programlarında sarmal programlama yaklaşımlarına yer verilmesi gerekmektedir.

Sarmal programlama yaklaşımında öğretim süreci doğrusal bir sırayla ilerlemez. $\mathrm{Bu}$ programda daha önceki öğrenmeler tekrar edilir ve tekrar edilen bilgiler sadece hatırlatma yapmakla kalmaz aynı zamanda konunun kapsamını da genişletir. Özellikle dil öğretim süreçleri için kullanılan sarmal programlama yaklaşımında her konunun kendi içerisindeki konuları ile bir ardışıklığı bulunur (Demirel, 2014, s.127).

Türkçenin yabancı dil olarak öğretiminde bir dil bilgisi yapısı tam olarak öğretilmeden yeni bir yapıya geçilmemesi gerekir. Bu ilke Türkçenin yabancı dil olarak öğretiminde üzerinde durulması gereken en önemli husustur (Barın, 2004, s. 23). Bu anlamda Türkçenin yabancı dil olarak öğretiminde herhangi bir seviyeden bir üst seviyeye geçişin sağlanması için ilgili seviyenin kazanımlarına yeterli düzeyde sahip olunduğunun bilinmesi gerekmektedir. Aksi takdirde tam olarak gerçekleşmemiş öğrenmeler dilin istenilen seviyede ilgili yeterliklere uygun olarak kullanılabilmesinin önüne geçebilmektedir.

Ölçme-değerlendirme, dil öğretim sürecinde öğrencilerin dil yeterliklerinin belirlenmesinde geri bildirim sunması itibarıyla öğretim sürecinin tekrar gözden geçirilmesine olanak tanımaktadır (Boylu, 2019, s. 2). Dil öğretim süreci içerisinde gerçekleştirilen ölçme ve değerlendirmelerde ilgili seviyenin kazanımları yazma becerisinde daha açık bir şekilde görülebilmekte ve süreç hakkında daha yararlı geri bildirimler sunulabilmektedir.

Diller İçin Avrupa Ortak Önerleri Çerçevesi'nde yetkin dil kullanımı olarak belirtilen $\mathrm{C} 1$ seviyesindeki bir öğrencinin $\mathrm{A} 1$, A2, B1 ve B2 düzeylerinde belirtilen 
yeterliklere sahip olması ve yazma sinavında alt düzey yeterliklere ait hataları nispeten daha az yapması beklenir. Çünkü daha önceki seviyelere ait yeterliklerin ilgili seviyelere ait sınavlarda edinilip edinilmediği belirlenmiş olmalı ve bu belirlemeye göre öğrencilerin bir üst kura geçmiş olmaları gerekir. Dil öğretim süreci içerisinde öğrencilerin $\mathrm{C} 1$ seviyesinde gerçekleştirdikleri sınavda daha alt becerilere ait kazanımlarda hatalar görülmekte ise dil öğretim sürecine ait öğretim programının, süreç içerisinde kullanılan öğretim setinin ve gerçekleştirilen ölçmedeğerlendirme sürecinin gözden geçirilmesinde yarar bulunmaktadır. Alt seviyelere ait hata yoğunluğu yüksek olan dil bilgisi yapılarının öğretiminde kullanılan öğretim yöntem ve tekniklerinin, ilgili yapılara ayrılan sürenin ve ilgili dil bilgisi yapılarına ait süreç içerisindeki tekrarların yeniden düzenlenmesi gerekmektedir.

\section{Türkçenin Yabancı Dil Olarak Öğretiminde Yazma Becerisi}

"Yazma, bireyin istek, hayal, izlenim, tasarı, zihninde ürettiği düşünce ve duygularını yazı ile dışa vurmasıdır" (Çelik, 2019, s. 271). Aynı zamanda yazma; uygulama ve somutlaştırmaya da izin veren bir süreç olup öğrencilerin düşüncelerini genişletmelerine, bilgilerini düzenlemelerine ve genişletmelerine, zihinsel sözlüklerini geliştirmelerine ve dili kullanma yeterliklerini artırmalarına yardımcı olur (Güneş, 2019, s. 154).

Yazma becerisi, dil öğrenme sürecinde en çok zaman alan ve geliştirilmesi zor olan bir beceridir (İlter, 2014, s. 38). Ana dili edinimi ve eğitimi süreci incelendiğinde bireylerin dört temel dil becerisinden ilk olarak sadece dinleme becerisinde faal olduğu görülmektedir. İnsanoğlu birtakım fiziksel ve zihinsel gelişimlere koşut olarak zaman içerisinde konuşma becerisini de etkinleştirmekte, okuma ve yazma becerisine genel olarak eğitim - öğretim süreci içerisinde geçiş yapmaktadır. Okuma becerisi eğitimi, her ne kadar bireyin okul hayatı ile başlasa da bireyler günümüz teknolojisinde yaşanan gelişmeler ile birlikte okul hayatına başlamadan önce de yoğun bir şekilde görsel ve yazınsal okuma ile karşılaşmaktadır. Bireylerin ana dili edinimi ve eğitimi süreci içerisinde yazma becerisi ile karşılaşmaları ise fiziksel gelişimler ile birlikte değerlendirildiğinde genel olarak okul hayatı ile başlamaktadır. Yazma becerisi bu anlamda ana dili ediniminde ve eğitiminde bireylerin en son karşılaştıkları beceri olarak karşımıza çıkmaktadır.

Yetişkin bireyler açısından yabancı dil öğretimi süreci değerlendirildiğinde özel amaçlı dil öğretim durumları haricinde bireylerin yabancı dil öğretiminde dört temel beceri esaslı bir öğretim süreci içerisinde ilerlemeleri beklenir. Yetişkin bireylere yönelik gerçekleştirilen yabancı dil öğretim süreçleri ana dili edinimi süreçlerinden farklı bir şekilde gerçekleşir. Çünkü ana dili edinimi sürecinde bireylerin dört temel dil becerisine aynı anda eşit bir şekilde yer vermesi fiziksel ve zihinsel gelişimler açısından mümkün değildir. Oysa yabancı dil öğretimi sürecinde yer alan yetişkin bireylerin fiziksel ve zihinsel gelişimleri dört temel dil becerisi esaslı bir öğretimin gerçekleşmesine olanak tanımaktadır. Yetişkin bireylere yönelik gerçekleştirilen yabancı dil öğretimi süreci içerisinde her ne kadar dört temel dil becerisine eşit oranda yer verilse de bireylerin yazma becerindeki gelişimlerinin diğer dil becerilene oranla daha geride kaldığı görülmektedir. 
Yazma, diğer dil becerileriyle doğrudan ilişkili bir beceri olup geliştirilmesi için diğer dil becerilerine yoğun bir şekilde ihtiyaç duyulmaktadır. Diğer dil becerilerinin gelişimi, yazma becerisinin gelişimi açısından önem taşıdığı gibi yazma becerisinin gelişimi de diğer dil becerilerinin gelişimine katkı sunmaktadır.

\section{Türkçenin Yabancı Dil Olarak Öğretiminde Yazma Becerisi ve Dil Bilgisi Arasındaki İlişki}

Dil, üç temel öğrenme alanından oluşmaktadır. Bu öğrenme alanları; şekil 1'de de görüldüğü üzere anlama, anlatma ve bu iki alanın daha etkili olmasını sağlayan dil bilgisi alanıdır (Göçer, 2019, s. 24).

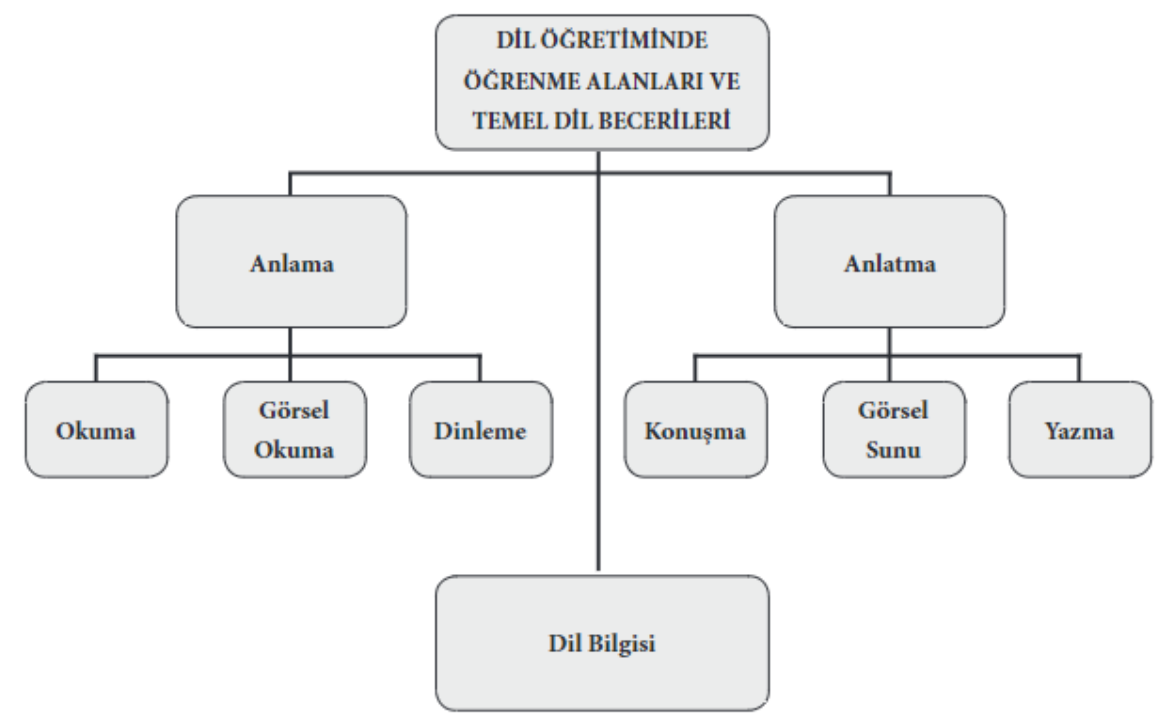

Şekil 1. Dil öğretiminde öğrenme alanları ve temel dil becerileri

Dil bilgisi; dilin doğru bir şekilde okunup yazılması ve doğru bir şekilde konuşulması usullerini gösteren, düşünce ve duyguları daha düzgün ve tam olarak anlamaya yardım eden pratik bir bilgi koludur (Banguoğlu, 1986, s. 4). Bu bağlamda dil bilgisi; anlama ve anlatma becerileri içerisinde oldukça önemli bir konuma sahiptir. Dil bilgisi yeterliği tam olarak sağlanmadan anlama ve anlatma becerilerinde istenilen düzeye ulaşmak mümkün değildir. Dil bilgisi yeterliğindeki eksiklik, iletişim kopukluklarının yaşanmasını özellikle yazma becerisinde diğer dil becerilerine oranla daha fazla artırmaktadır. Dil bilgisi kurallarının okunan veya dinlenen bir metinden doğru bir şekilde anlaşlabilmesi Bloom Taksonomisi'ne göre daha alt basamaklarda yer alan yeterlikleri işaret ederken; öğrenilmiş olan bu dil bilgisi kurallarının yeni örnekler içerisinde kullanılabilmesi daha üst basamak yeterliklere işaret etmektedir. Bu anlamda dil bilgisi kurallarını anlatma becerileri içerisinde kullanabilecek yeterliğe ulaşabilmek anlama becerilerindeki dil bilgisi kurallarını anlamlandırabilmekten daha zordur. $\mathrm{Bu}$ da anlatma becerilerinde dil bilgisinden kaynaklı iletişim kopukluklarının daha fazla olmasına sebebiyet vermektedir. Anlatma becerileri içerisinde yazma becerisinde yaşanan dil 
bilgisinden kaynaklı iletişim kopukluklarının konuşma becerisinde yaşanan dil bilgisinden kaynaklı iletişim kopukluklarından daha fazla olması beklenir. Çünkü konuşma becerisi ortaya koyulurken kaynak ile alıcı arasında doğrudan bir etkileşim içerisinde bulunulmaktadır. Kaynağın doğrudan doğruya alıcı ile etkileşim içerisinde bulunması beden dilinin devreye girmesini ve anlatılmak istenenlerin daha kolay anlatılmasına yardımcı olmakta böylece yanlış dil kullanımlarının ortaya çıkaracağı iletişim kopuklukları azalabilmektedir. Yazma becerisinde ise kaynak ile alıcının doğrudan bir arada bulunmaması yanlış dil kullanımlarından kaynaklı iletişim kopukluklarını azaltabilecek konuşma becerisindeki yardımcı unsurlara olanak tanımamaktadır. $\mathrm{Bu}$ sebeple dil öğrenicisinin sahip olduğu bilgileri yanlış anlaşılmalara sebebiyet vermeksizin hatasız bir şekilde yazıya dökmesi beklenir. Bilgilerin yazıya aktarımı sürecinde dil bilgisi kuralları büyük önem taşımaktadır.

Diller İçin Avrupa Ortak Öneriler Çerçevesi’nde “Dilbilgisi yeterliği, söz konusu kurallara uygun iyi biçimlendirilmiş ifadeler ve cümleler üretme ve tanıma yeteneği" olarak tanımlanmaktadır (AK/MDB, 2013, s. 114). Dil bilgisi iletişimsel olarak anlama ve anlatma becerilerini desteklemesi açısından önem kazanmaktadır. İletişimsel olarak anlama ve anlatma becerilerine katkı sağlamayan dil bilgisi kurallarının yabancı dil öğretimi içerisinde yer edinmesi anlamsızdır. Dil bilgisi kurallarının iletişimsel yönü itibarıyla uygulamaya imkân veren bir öğretim sürecinin içerisinde yer alması gerekir. Bu bağlamda yabancı dil öğretimi sürecinde öğrenilenlerin Bloom Taksonomisi'ne göre daha üst basamak yeterliklerde ortaya koyulmasına imkân sunan anlatma becerileri içerisinde geri dönütler sağlanarak değerlendirilmesinde yarar bulunmaktadır. Dil bilgisi kurallarının iletişimsel anlamda uygulamaya yönelik olarak kullanılıp kullanılmadığına dair geri bildirimlerin sunulmasında yazma becerisi daha net veriler sunar. Feng ve Powers (2005, s. 70) tarafindan yapılan bir araştırmada dil öğreticilerinin dil bilgisini yazma sürecine özellikle de geri dönüt aşamalarına dâhil etmeleri gerektiği ve bu süreçte öğrenicilerinin sık yaptıkları hatalara aşina olmaları gerektiği ifade edilerek hataya dayalı gramer öğretiminin dil öğretiminde etkili bir yol olduğu sonucuna ulaşılmıştır. Çünkü yazma becerisi diğer temel dil becerileri ve dil bilgisi kuralları aracılığıyla bir ürünün ortaya çıkmasını sağladığı için gözlemlemeye en açık olan beceridir (Korkmaz, 2019, s. 175).

\section{Problem Durumu}

Çalışmanın temel problem durumunu "Yabancı dil olarak Türkçe öğrenenlerin C1 sınavı yazma becerisinde yaptıkları dil bilgisi hatalarının seviyelere göre dağılımı nasıldır?" sorusu oluşturmaktadır. Çalışma, bu problem durumundan hareketle aşağıdaki alt sorulara cevap aramaktadır.

- Yabancı dil olarak Türkçe öğrenenlerin C1 sınavı yazma becerisinde yaptıkları A1 seviyesindeki dil bilgisi hataları nelerdir?

- Yabancı dil olarak Türkçe öğrenenlerin C1 sınavı yazma becerisinde yaptıkları A2 seviyesindeki dil bilgisi hataları nelerdir?

- Yabancı dil olarak Türkçe öğrenenlerin C1 sinavı yazma becerisinde yaptıkları B1 seviyesindeki dil bilgisi hataları nelerdir? 
- Yabancı dil olarak Türkçe öğrenenlerin C1 sınavı yazma becerisinde yaptıkları B2 seviyesindeki dil bilgisi hataları nelerdir?

\section{Yöntem}

\section{Araştırmanın Modeli}

Yabancı dil olarak Türkçe öğrenenlerin C1 sınavı yazma becerisinde yapmış oldukları dil bilgisi hatalarını seviyelere göre tespit etmeyi amaçlayan bu çalışmada nitel araştırma desenlerinden durum (örnek olay) çalışması kullanılmıştır. Durum çalışmalarında doküman, gözlem, görüşme, odak grup görüşmesi yoluyla toplanan veriler betimsel analiz ya da içerik analizi yoluyla analiz edilebilir (Yıldırım ve Şimşek, 2016, s. 297). Çalışmada doküman incelemesine başvurulmuş olup verilerin analiz edilmesinde içerik analizinden yararlanılmıştır. İçerik analizinde amaç, eldeki verileri açıklayabilecek kavram ve ilişkilere ulaşmaktır. İçerik analizi yoluyla veriler tanımlanmaya, içinde saklı olabilecek gerçekler ortaya çıkarılmaya çalışılır ve okuyucunun anlayabileceği şekilde düzenlenerek yorumlanır (Yıldırım ve Şimşek 2016, s. 242).

\section{Verilerin Toplanması ve Çözümlenmesi}

Araştırmanın verilerini 2018-2019 akademik yılında Ankara Yıldırım Beyazıt Üniversitesi Dil Eğitimi Uygulama ve Araştırma Merkezinde C1 seviyesinde öğrenim gören 43 öğrencinin C1 yazma sınavındaki sorulara verdikleri cevaplar oluşturmaktadır.

Öğrencilerin $\mathrm{C} 1$ yazma sınavında yapmış oldukları dil bilgisi hataları seviyelere göre tespit edilmiştir. Dil bilgisi konularının seviyelendirilmesinde ve sınıflandırılmasında çalışma grubundaki öğrencilerin Türkçe öğrenim süreci içerisinde kullanmış oldukları Yedi İklim Türkçe Öğretim Seti’nde belirtilen dil bilgisi kuralları esas alınmıştır. Yedi İklim Türkçe Öğretim Seti’nde yer alan dil bilgisi kurallarının seviyelere göre belirlenmesinde İltar (2018) tarafindan ortaya koyulan sınıflandırma kullanılmıştır.

\section{Çalışma Grubu}

Araştırmanın çalışma grubu, 2018-2019 akademik yılında Ankara Yıldırım Beyazıt Üniversitesi Dil Eğitimi Uygulama ve Araştırma Merkezinde öğrenimine A1 seviyesinde başlayıp C1 seviyesinin sonuna kadar sürdüren ve C1 sınavına katılan 43 öğrenci oluşturmaktadır. Araştırmaya katılan öğrencilerin kişisel bilgileri şu şekildedir:

Tablo 1.

Araştırmaya Katılan Öğrencilerin Ülkelere Göre Dağılımına İlişkin Bilgiler

\begin{tabular}{ccc}
\hline Ülke & f & $\%$ \\
\hline Afganistan & 1 & 2 \\
Bangladeş & 1 & 2 \\
Benin & 1 & 2 \\
Cezayir & 3 & 7 \\
Fas & 2 & 5 \\
Filistin & 1 & 2
\end{tabular}




\begin{tabular}{ccc} 
Gana & 1 & 2 \\
Hindistan & 1 & 2 \\
Irak & 3 & 7 \\
İran & 3 & 7 \\
Karadăg & 1 & 2 \\
Kazakistan & 1 & 2 \\
Kenya & 2 & 5 \\
Libya & 1 & 2 \\
Maldivler & 1 & 2 \\
Mozambik & 1 & 2 \\
Ruanda & 1 & 2 \\
Rusya & 1 & 2 \\
Senegal & 1 & 2 \\
Somali & 8 & 19 \\
Sudan & 1 & 2 \\
Suriye & 3 & 7 \\
Tayvan & 1 & 2 \\
Ürdün & 3 & 7 \\
Toplam & 43 & 100 \\
\hline
\end{tabular}

Tablo 2.

Araştırmaya Katılan Öğrencilerin Cinsiyete Göre Dağılımına İlişkin Bilgiler

\begin{tabular}{ccc}
\hline Cinsiyet & f & $\%$ \\
\hline K1z & 23 & 53 \\
Erkek & 20 & 47 \\
Toplam & 43 & 100 \\
\hline
\end{tabular}

Tablo 3.

Araştırmaya Katılan Öğrencilerin Öğrenim Düzeyine İlişkin Bilgiler

\begin{tabular}{ccc}
\hline Öğrenim Düzeyi & f & $\%$ \\
\hline Lisans & 23 & 53 \\
Yüksek Lisans & 8 & 19 \\
Doktora & 12 & 28 \\
Toplam & 43 & 100 \\
\hline
\end{tabular}

\section{Bulgular ve Yorumlar}

\section{Yabancı Dil Olarak Türkçe Öğrenenlerin C1 Sınavı Yazma Becerisinde Yaptıkları A1 Seviyesindeki Dil Bilgisi Hataları}

Öğrencilerin C1 yazma sınavında yapmıș oldukları A1 seviyesindeki dil bilgisi hataları sayısal ve yüzdelik değer bakımından grafiklerde gösterilmiştir. 
Yabancı Dil Olarak Türkçe Öğrenenlerin C1 Sınavı Yazma Becerisinde Yaptıkları A1 Seviyesindeki Dil Bilgisi Hatalarının Sayısal Dağılımı

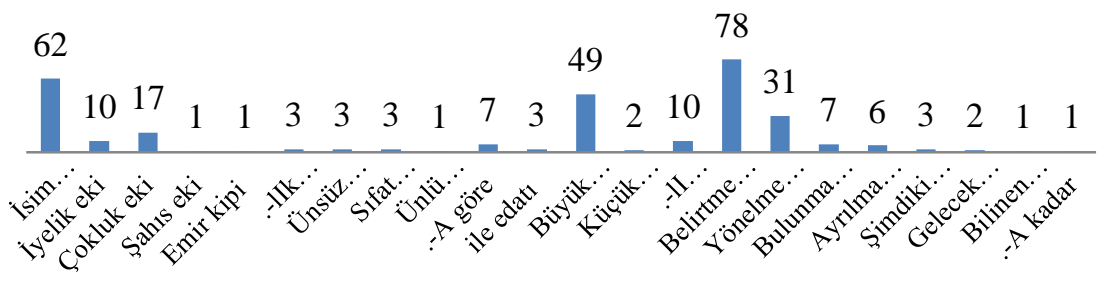

Şekil 2. A1 dil bilgisi hatalarının sayısal dağılımı

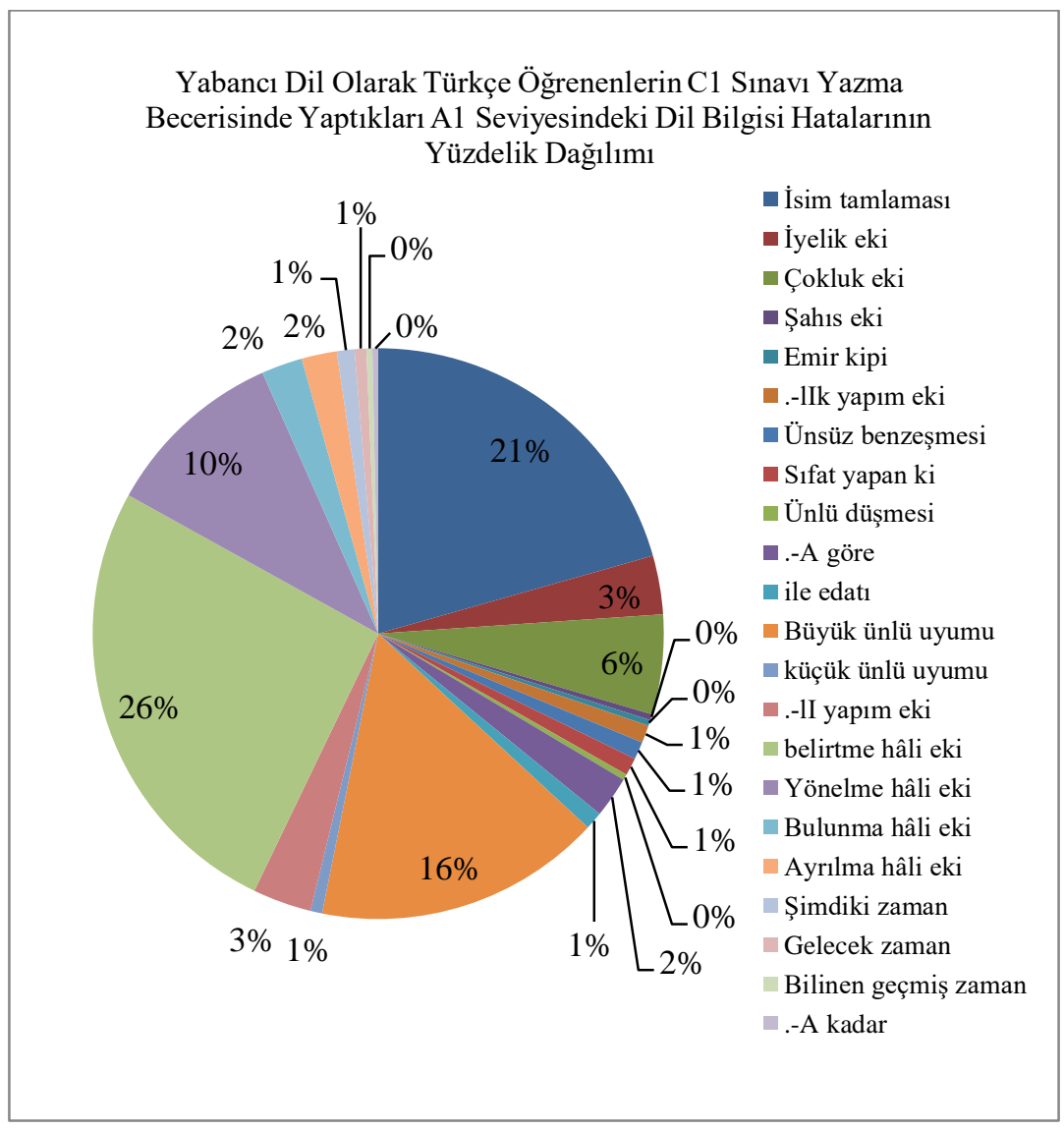

Şekil 3. A1 dil bilgisi hatalarının yüzdelik dağılımı

43 öğrenciye ait olan $\mathrm{C} 1$ yazma sınavında A1 seviyesinden 22 farklı dil bilgisi kuralına ait hata bulunmaktadır. İlgili dil bilgisi kurallarına ait hataların öğrencilerin yazma evraklarında $301 \mathrm{kez}$ yer aldığı tespit edilmiştir. Yedi İklim Türkçe Öğretim Seti A1 seviyesinde öğretiminin gerçekleştirildiği belirtilen işaret sıfatı (bu, şu, o), 
soru zamiri (ne), işaret zamiri (burada, şurada, orada), soru zamiri (nerede), soru zamiri (kim), işaret zamiri (burası, şurası, orası), soru zamiri (neresi), var-yok, soru edatı, ek fiilin olumsuzu (değil), sayılar, yapım eki (-IncI), emir kipi, edat grubu (DAn önce, -DAn sonra), bağlaç (ile), istek kipi, zamir yapan “-ki”, karşılaştırma derecesi (zarf: daha), karşılaştırma derecesi (zarf: en), görelik eki (-cA), edat gubu (-DAn beri), zarf (-dır) dil bilgisi kuralları yazma evraklarında yer almakta olup hatasız bir şekilde kullanılmıştır.

C1 yazma sınavinda yer alan 22 farklı dil bilgisi kuralına ait hatalar incelendiğinde hataların en çok belirtme hâli eki, isim tamlaması, büyük ünlü uyumu, yönelme hâli eki ve çokluk ekinde tekrar ettiği görülmektedir.

A1 Seviyesine Ait Dil Bilgisi Yanlışlarından Örnekler:

Ö. 3: Herkes kendi ülkesi üst seviyelerde görmek ister (Belirtme hâli eki)

Ö. 21: Aslında salgın hastalıklarının ilaçları ve tedaviler maalesef çok pahalı olduğu için özellikle gelişmemiş ülkelerde bu hastalar azalması engelleniyor. (isim tamlamasl)

Ö. 1: Bence çevreyi korumaliyiz ve ormanlari çoğaltmaliyiz. (Büyük ünlü uyumu)

Ö. 5: 3500 kilometre mesafe ile dünyanın en uzun sahili sahip ülke Fas'tır. (Yönelme hâli eki)

Ö. 17: Şu anda ülkemiz çok gelişmiş değil ve ülkemizde birkaç mücadeleler var ama umarım elli yıl sonra daha iyi olacak. (Çokluk eki)

\section{Yabancı Dil Olarak Türkçe Öğrenenlerin C1 Sınavı Yazma Becerisinde Yaptıkları A2 Seviyesindeki Dil Bilgisi Hataları}

Öğrencilerin C1 yazma sınavında yapmış oldukları A2 seviyesindeki dil bilgisi hataları sayısal ve yüzdelik değer bakımından grafiklerde gösterilmiştir.

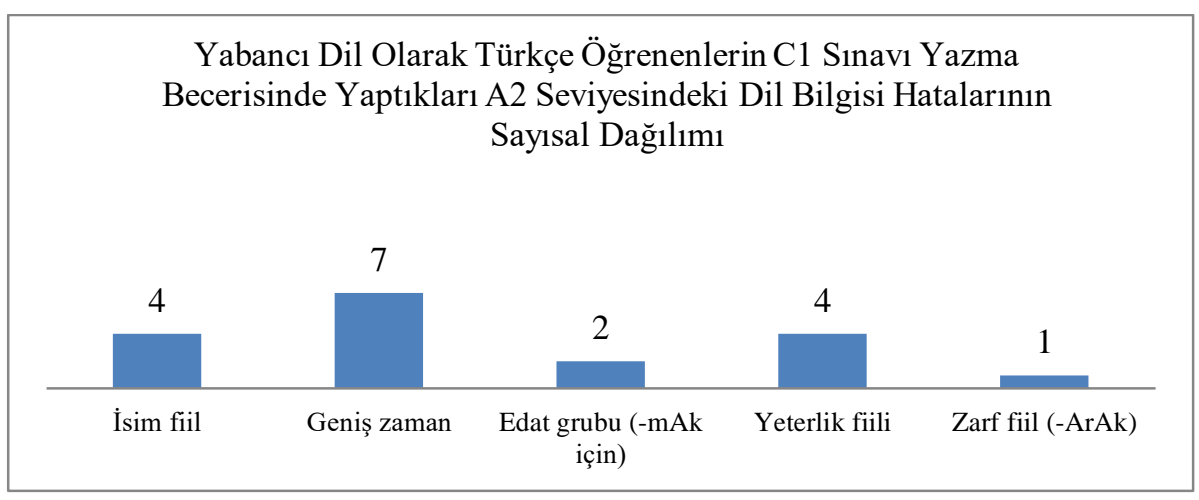

Şekil 4. A2 dil bilgisi hatalarının sayısal dağılımı 
Yabancı Dil Olarak Türkçe Öğrenenlerin C1 Sınavı Yazma

Becerisinde Yaptıkları A2 Seviyesindeki Dil Bilgisi Hatalarının

Yüzdelik Dağılımı

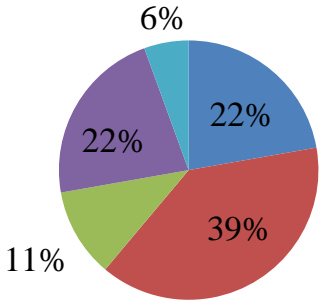

İsim fiil

- Geniş zaman

Edat grubu (-mAk için)

yeterlik fiili

Zarf fiil (-ArAk)

Şekil 5. A2 dil bilgisi hatalarının yüzdelik dağılımı

43 öğrenciye ait olan $\mathrm{C} 1$ yazma sınavında A2 seviyesinden 5 farklı dil bilgisi kuralına ait hata bulunmaktadır. İlgili dil bilgisi kurallarına ait hataların öğrencilerin yazma evraklarında $18 \mathrm{kez}$ yer aldığı tespit edilmiştir. Yedi İklim Türkçe Öğretim Seti A2 seviyesinde öğretimi gerçekleştirildiği belirtilen dil bilgisi kurallarından "zarf fiil (-mAdAn önce, -DIktAn sonra), belirsiz geçmiş zaman, ek fiilin belirli geçmiş zamanı, ek fiilin belirsiz geçmiş zamanı, pekiştirme, edat (için), bağlaç (çünkü), edat (kadar, gibi), edat grubu (bu yüzden, bu sebeple), eşitlik-görelik eki (cA), tekrarlı bağlaç (hem... hem), tekrarlı bağlaç (ne...ne), tekrarlı bağlaç (ya....ya), zarf fiil (-Ip), zarf fiil (-mAdAn), zarf fiil (-A...-A), edat (diye), edat grubu (-mAk üzere)" yazma evraklarında yer almakta olup hatasız bir şekilde kullanılmıştır. "İkileme, tekrarlı bağlaç (belki ... belki), tekrarlı bağlaç (ister...ister), dolaylı anlatım (emir cümlelerinde)" yazma evraklarında öğrenciler tarafından hiç kullanılmamıştır.

C1 yazma sınavında yer alan 5 farklı dil bilgisi kuralına ait hatalar incelendiğinde hataların tekrar sıklığına göre sırasıyla geniş zaman, isim fiil, yeterlik fiili, edat grubu (-mAk için), zarf fiil (ArAk)'den oluştuğu görülmektedir.

A2 Seviyesine Ait Dil Bilgisi Yanlışlarından Örnekler:

Ö: 32: Bir ülkeyi bilerken yemeklerinin nasll olduğunu bilebilmek gerekir. (Geniş zaman)

Ö. 18: Keşke çok para olsaydı en büyük alışveriş dükkanını açmıştım ve herkes çalışmak başlardl. (İsim fiil)

Ö. 40: Tabi başka bir ülkede yaşabilir ama onun vatanı kalbimizde özel bir yer altyor.(Yeterlik Fiili)

Ö. 8: Ülkemizin bir hedefi vardır ve o hedefi gerçekleştirme için peşinden koşmalıyız. (Edat grubu-mAk için)

Ö. 3: Ülkede okulları bedava yapmaya başlarak her şey daha iyi olabilir. Zarf fiil (ArAk) 


\section{Yabancı Dil Olarak Türkçe Öğrenenlerin C1 Sınavı Yazma Becerisinde Yaptıkları B1 Seviyesindeki Dil Bilgisi Hataları}

Öğrencilerin C1 yazma sınavında yapmış oldukları B1 seviyesindeki dil bilgisi hataları sayısal ve yüzdelik değer bakımından grafiklerde gösterilmiştir.

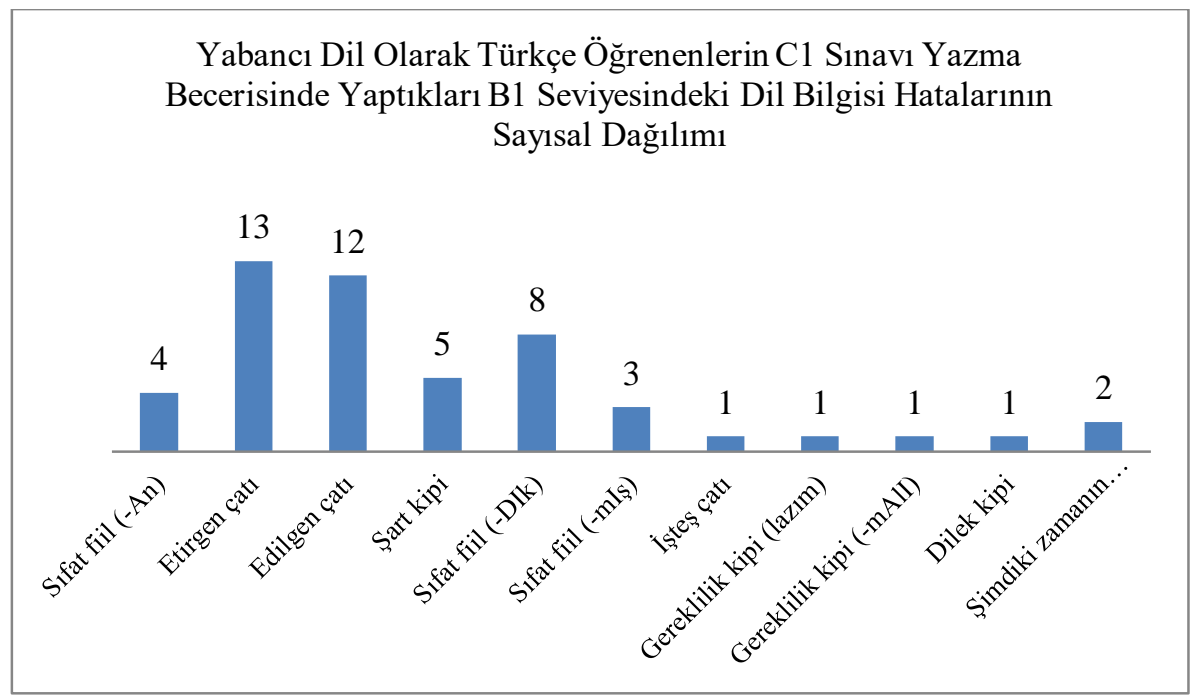

Şekil 6. B1 dil bilgisi hatalarının sayısal dağılımı

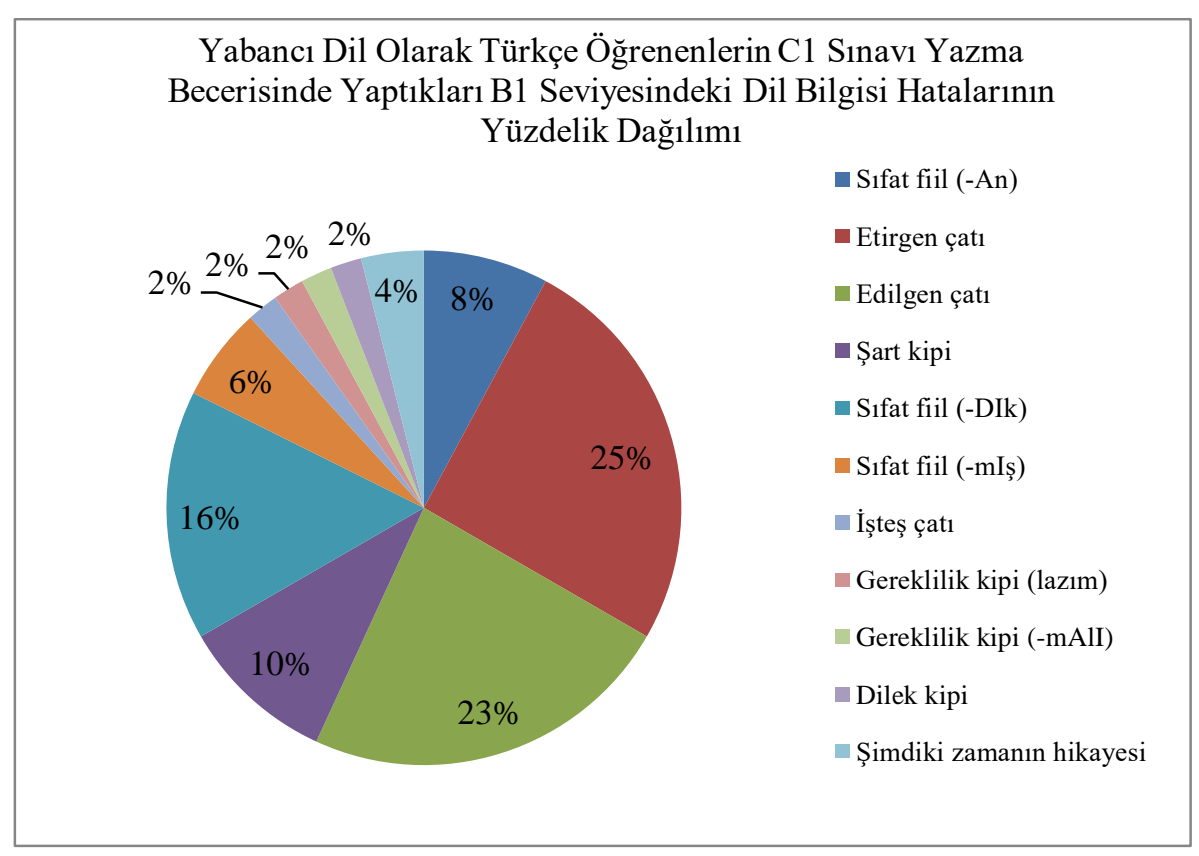

Şekil 7. B1 dil bilgisi hatalarının yüzdelik dağılımı 
43 öğrenciye ait olan $\mathrm{C} 1$ yazma sınavında $\mathrm{B} 1$ seviyesinden 11 farklı dil bilgisi kuralına ait hata bulunmaktadır. İlgili dil bilgisi kurallarına ait hataların öğrencilerin yazma evraklarında $51 \mathrm{kez}$ yer aldığı tespit edilmiştir. Yedi İklim Türkçe Öğretim Seti B1 seviyesinde öğretimi gerçekleştirildiği belirtilen dil bilgisi kurallarından "Ek fiilin zarfı (-ken), ek fiilin geniş zamanı, edat grubu (-DIğIndan beri), Zarf fiil (AlI), dönüşlü çatı, dönüşlü zamir, sıfat fiil (-AcAk), zarf fiil (-DIğIndA), zarf fiil (DIğI zaman)" yazma evraklarında yer almakta olup hatasız bir şekilde kullanılmıştır.

C1 yazma sınavında yer alan 11 farklı dil bilgisi kuralına ait hatalar incelendiğinde hataların en çok sırasıyla ettirgen çatı, edilgen çatı, sıfat fiil (-DIk), şart kipi, sıfat fiil (-An)'de tekrar ettiği görülmektedir.

B1 Seviyesine Ait Dil Bilgisi Yanlışlarından Örnekler:

Ö. 9: Bence bu hayali gerçekleşmek için doğal kaynaklarımız adil bir şekilde üretmeliyiz. (Ettirgen çatı)

Ö. 28: Avrupa Birliğin'deki ortak siyaset, seçim ve medyada en çok konuşan sorun göçtür. (Edilgen çatı) DIk)

Ö. 20: Bence dünyada salgın hastalıkların oldumağı yer mümkündür. (Sıfat fiil -

Ö. 34: Ĕ̆ger, biz vatandaşlar olarak, uygun liderler seçerseyiz, bu hâli mumkun olacak. (Şart kipi)

Ö. 13: Dünyamızı yaşanmaz yapayan sebeplerinden biri salgın hastalıklardır. (Sifat fiil -An)

\section{Yabancı Dil Olarak Türkçe Öğrenenlerin C1 Sınavı Yazma Becerisinde Yaptıkları B2 Seviyesindeki Dil Bilgisi Hataları}

Öğrencilerin C1 yazma sınavında yapmış oldukları B2 seviyesindeki dil bilgisi hataları sayısal ve yüzdelik değer bakımından grafiklerde gösterilmiştir.

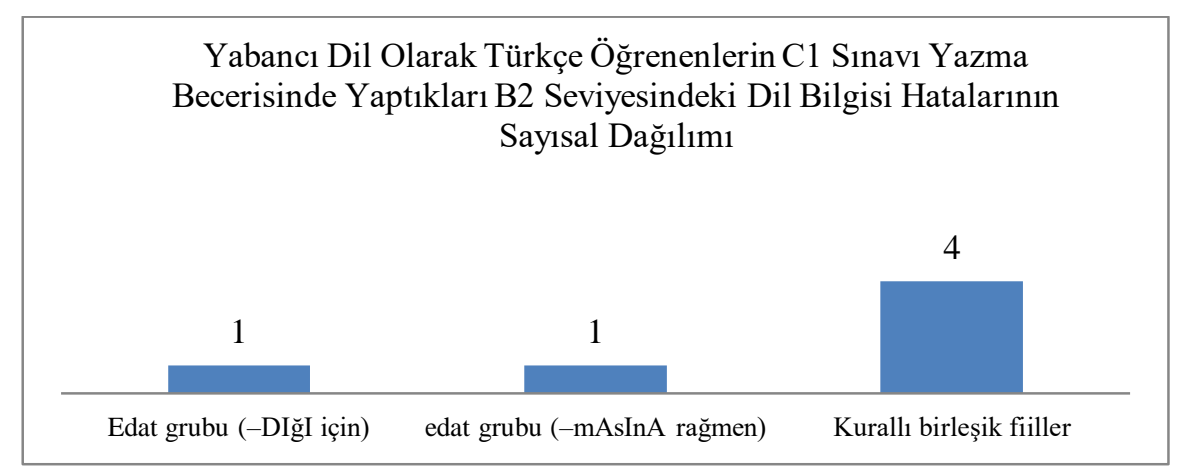

Şekil 8. C1 dil bilgisi hatalarının sayısal dağılımı 


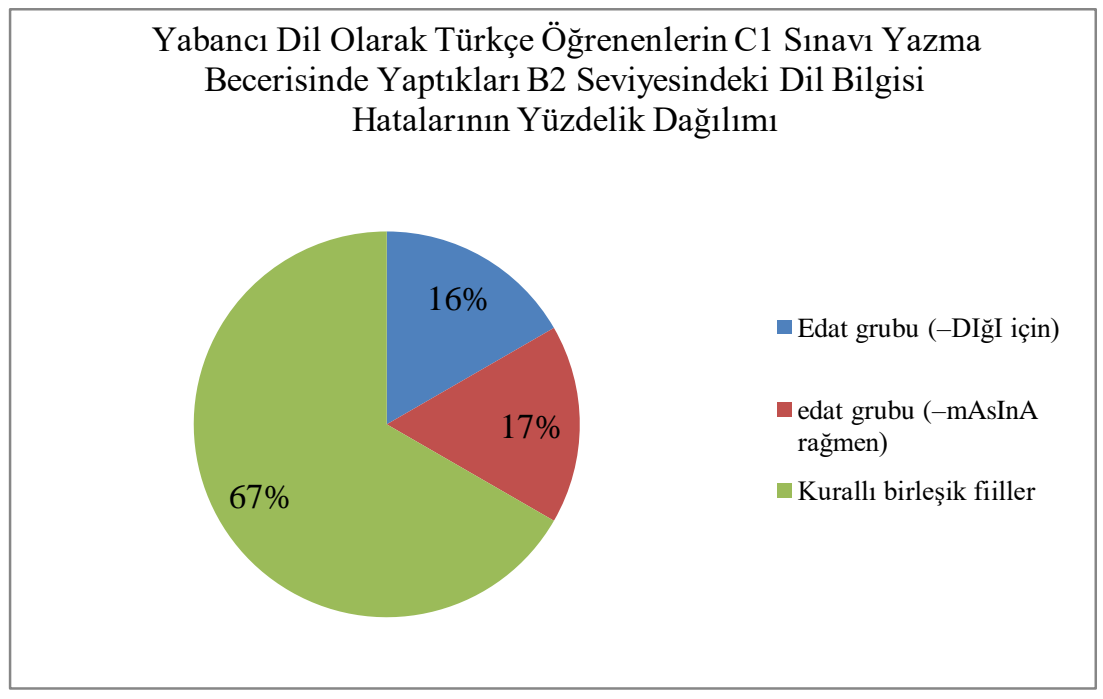

Şekil 9. C1 dil bilgisi hatalarının yüzdelik dağılımı

43 öğrenciye ait olan C1 yazma sınavında B2 seviyesinden 3 farklı dil bilgisi kuralına ait hata bulunmaktadır. İlgili dil bilgisi kurallarına ait hataların öğrencilerin yazma evraklarında $6 \mathrm{kez}$ yer aldığı tespit edilmiştir. Yedi İklim Türkçe Öğretim Seti B1 seviyesinde öğretimi gerçekleştirildiği belirtilen dil bilgisi kurallarından "hikâye birleşik zamanları, edat grubu (-IncAyA kadar), edat grubu (-AnA kadar), sıfat fiil $(-\mathrm{Ar})$, sıfat fiil $(-\mathrm{mAz})$, sıfat fiil $(-\mathrm{mIşs})$, zarf fiil (-DIğI sırada), rivayet birleşik zamanları, edat (boyunca, süresince), zarf fiil (-DIğI sürece, -DIğI zaman ), zarf fiil (-Dikça), zarf fiil (-IncA), edat grubu (-AcAğındAn), edat grubu (-AcA ğ için), edat grubu (-DIğI hâlde), zar fiil (-mAk yerine, -mAktAnsA), zarf fiil (AcAğınA, -AcAğI yerde) Zarf fiil (-mAsI durumunda)" yazma evraklarında yer almakta olup hatasız bir şekilde kullanılmıştır.

“Zarf fiil (-mAksIzIn) Sıfat fiil (-AsI), dolaylı anlatım (isim cümlesi, fiil cümlesi, istek kipi, soru cümlesi, emir kipi), zarf fiil (-Ar...-mAz), dolaylı anlatım (gereklilik kipi), edat grubu (-AcAğI hâlde), edat grubu (-DIğI takdirde, -mAsI hâlinde), zarf fiil (-AcAğI zaman, -AcAğı sırada)" yazma evraklarında öğrenciler tarafından hiç kullanılmamıştır.

C1 yazma sınavında yer alan 3 farklı dil bilgisi kuralına ait hatalar incelendiğinde hataların tekrar sıklığına göre sırasıyla kurallı birleşik fiiller, edat grubu (--mAsInA rağmen), edat grubu (-DIğI için)'ndan oluştuğu görülmektedir.

B2 Seviyesine Ait Dil Bilgisi Yanlışlarından Örnekler:

Ö. 6: Geçen sene ekonominin sorunları bir anda bitekald. (Kurallı birleşik fiiller)

Ö. 19: Ürdün küçük olduğuna rağmen turizme göre çok zengindir. (Edat grubu mAsInA ră̆men) 
Ö. 38: Ülke fakır olduğundan beri insanların refah durumu yeterli olmadıkları için insanlar da yoksuldur. (Edat grubu-DIğI için)

\section{Tartışma ve Sonuç}

Araştırma kapsamında C1 seviyesinde yer alan 43 öğrenciye yönelik olarak gerçekleştirilen yazma sınavında öğrencilerin kullandıkları Yedi İklim Türkçe Öğretim Seti'nde belirtilen dil bilgisi yapılarına ait hatalar seviyelere göre incelenmiştir. İnceleme sonucunda öğrencilerin A1 seviyesinde yer alan 22 farklı dil bilgisi kuralında $301 \mathrm{kez}$, A2 seviyesinde yer alan 5 farklı dil bilgisi kuralında 18 kez, B1 seviyesinde yer alan 11 farklı dil bilgisi kuralında $51 \mathrm{kez}$ ve B2 seviyesinde yer alan 3 farklı dil bilgisi kuralında 6 kez hata tekrarı yaptığ 1 tespit edilmiştir. Yedi İklim Türkçe Öğretim Seti'nde C1 seviyesinde herhangi bir dil bilgisi yapısına ait öğretim yer almadığı için C1 seviyesi inceleme kapsamı dışında bırakılmıştır.

A1 seviyesinde yer alan dil bilgisi yapılarına ait hatalar tekrar sayısına göre sırasıyla şu şekildedir: $78 \mathrm{kez}$ belirtme hâli eki, $62 \mathrm{kez}$ isim tamlaması, 49 kez büyük ünlü uyumu, $31 \mathrm{kez}$ yönelme hâli eki, $17 \mathrm{kez}$ çokluk eki, $10 \mathrm{kez}$ iyelik eki, $10 \mathrm{kez}$ yapım eki (-1I), 7 kez edat (-A göre), 7 kez bulunma hâli eki, 6 kez ayrılma hâli eki, 3 kez yapım eki (-1Ik), 3 kez ünsüz benzeşmesi, 3 kez sıfat yapan ki, 3 kez edat (ile), 3 kez şimdiki zaman, 2 kez küçük ünlü uyumu, 2 kez gelecek zaman, 1 kez şahıs eki, 1 kez emir kipi, 1 kez ünlü düşmesi, 1 kez bilinen geçmiş zaman, 1 kez -A kadar.

A2 seviyesinde yer alan dil bilgisi yapılarına ait hatalar tekrar sayısına göre sırasıyla şu şekildedir: $7 \mathrm{kez}$ geniş zaman, $4 \mathrm{kez}$ isim fiil, $4 \mathrm{kez}$ yeterlik fiili, $\quad 2 \mathrm{kez}$ edat grubu (-mAk için), 1 kez zarf fiil (-ArAk).

B1 seviyesinde yer alan dil bilgisi yapılarına ait hatalar tekrar sayısına göre sırasıyla şu şekildedir: $13 \mathrm{kez}$ ettirgen çatı, $12 \mathrm{kez}$ edilgen çatı, 8 kez sıfat fiil (-DIk), 5 kez şart kipi, 4 kez sıfat fiil (-An), 3 kez sıfat fiil (-mIş), 2 kez şimdiki zamanın hikâyesi, 1 kez işteş çatı, 1 kez gereklilik kipi (lazım), 1 kez gereklilik kipi (-mAlI), 1 kez dilek kipi.

B2 seviyesinde yer alan dil bilgisi yapılarına ait hatalar tekrar sayısına göre sırasıyla şu şekildedir: $4 \mathrm{kez}$ kurallı birleşik fiiller, $1 \mathrm{kez}$ edat grubu (-mAsInA rağmen), 1 kez edat grubu (-DIğI için).

Tüm seviyeler esas alındığında 41 farklı dil bilgisi hatasının 376 kez tekrar ettiği tespit edilmiş olup en sık tekrar eden 5 dil bilgisi yapısına ait hatanın A1 seviyesinde yer aldığı görülmektedir. Hata olarak en sık tekrar eden beş dil bilgisi yapısının $\% 20,7$ ile belirtme hâli eki, \%16,4 ile isim tamlamas1, \%13 ile büyük ünlü uyumu, $\% 8,2$ ile yönelme hâli eki ve \%4,5 ile çokluk eki olduğu sonucuna ulaşılmıştır.

En sık tekrar eden beş dil bilgisi hatasından ikisinin belirtme hâli eki ve yönelme hâli ekinden oluştuğu görülmektedir. Güven (2007) tarafindan yapılan araştırmada temel, orta ve ileri düzeydeki yabancı öğrencilerin yazılı anlatım kâğıtları incelenip hâl eklerinde yaptıkları yanlışlar kendi içerisinde yüzdelik değer bakımından ortaya koyulmuştur. Çalışmaya göre temel seviyede belirtme hâli eki \%42, yönelme hâli eki \%23, bulunma hâli eki \%26, uzaklaşma hâli eki \%8 oranındadır. Orta seviyede 
belirtme hâli eki \%59, yönelme hâli eki \%29,4, bulunma hâli eki $\% 6,5$, uzaklaşma hâli eki \%5,2 oranındadır. İleri seviyede belirtme hâli eki \%59,4, yönelme hâli eki $\% 29$, bulunma hâli eki $\% 6,7$, uzaklaşma hâli eki $\% 4,7$ oranındadır. Tüm seviyelerdeki yanlış yapma oranlarına bakıldığında belirtme hâli eki \%52,7, yönelme hâli eki \%26,4, bulunma hâli eki \%14, uzaklaşma hâli eki \%6,2'dir. Güven (2007) tarafindan yapılan çalışmada hâl eklerinin kendi içerisindeki hata oranları ile bu çalışmadaki hâl eklerinin hata sıklığı benzerlik göstermektedir. Ayrıca Güven(2007) tarafından yapılan çalışmada hâl eklerinin seviyelere göre hata oranlarının birbirine yakın olduğu görülmektedir. Yine benzer şekilde Atagül ve Cevher (2015) tarafından yapılan çalışmada öğrencilerin hâl eklerini tam olarak nerede kullanacaklarını bilmedikleri, gerekli durumlarda hâl eklerini kullanmadıkları, iyelik eki ve ilgi eki ile karıştırdıkları, gerekli olmayan yerlerde kullandıkları sonucuna ulaşılmıştır. Candaş Karababa (2009, s. 273) tarafından yapılan çalışmada hâl eklerinin kullanımında yapılan yanlışların Türkçe öğretiminde önemli bir yere sahip olduğu, özellikle belirtme hâli eki ve yönelme hâli ekini kullanmakta öğrencilerin zorlandığı ifade edilmiştir. Kana ve Erol (2019) tarafindan yapılan çalışmada öğrencilerin en çok sorun yaşadıkları dil bilgisi yapısının hâl ekleri olduğu sonucuna ulaşılmıştır.

İsim tamlaması en sık tekrar edilen ikinci dil bilgisi yapısı olarak karşımıza çıkmaktadır. Hataların genel olarak tamlayan ve tamlanan eklerinin kullanılmamasından kaynaklandığı görülmektedir. Başoğul ve Can (2014, s. 104) tarafından yapılan çalışmada öğrencilerin yazma hatalarının en çok sırasıyla ses temelli yazım hataları, ad durum eklerinin kullanımı, isim ve sıfat tamlamalarının kullanımından kaynaklandığ 1 belirtilmiştir. Aynı çalışmada isim tamlamalarından kaynaklı hatalarla ilgili olarak özellikle öğrenciler tarafindan kurulan zincirleme isim tamlamalarında tamlayan ekinin kullanılmadığı veya fazladan tamlayan eki kullanıldığı belirtilmiştir. Şahin (2013, 443-444) tarafından yapılan çalışmada tamlama eklerinin kullanımının hâl eklerinden sonra en çok hata yapılan ikinci çekim eki olduğu belirtilerek hataların daha çok tamlama ekinin yazılmamasından kaynaklı olduğu belirtilmiştir.

Büyük ünlü uyumundan kaynaklı hatalar sıklık olarak üçüncü sırada yer almaktadır. Bu hatalar incelendiğinde hataların daha çok "1, i, o, ö, u, ü" seslerinden kaynakladığı görülmektedir. Bu durumun temel sebebinin alfabe farklılığından kaynaklı olduğu ileri sürülebilir. Açık (2008, s.3) tarafından yapılan çalışmada araştırmaya katılan öğrencilerin \%50'si yazım hatalarının alfabe kaynaklı olduğunu ifade etmiş ve yine aynı çalışmada öğrencilerin \%46'sının ünlü harflerin, \%21'inin ünsüz harflerin yazımında zorlandıkları tespit edilmiştir.

Çokluk ekinin kullanımı ile ilgili hatalar en sık yapılan beşinci hata olarak karşımıza çıkmaktadır. Çokluk eki ile yapılan hataların daha çok sayı sıfatları ve belgisiz sıfatlardan sonra gelen isimlerde yapıldı̆̆ 1 görülmektedir. Kara (2010) tarafından yapılan çalışmada benzer şekilde her gruptan birçok yabancı ögrencinin "bütün, tüm” gibi kelimelerden sonra gelen isimlerde çokluk ekini kullandığ belirtilmiştir. Şahin (2013, s. 443) tarafından yapılan çalışmada çokluk ekinin yazımının hâl ekleri ve tamlama eklerinden sonra, öğrencilerin en fazla hata yaptıkları çekim eki olduğu ifade edilmiş ve öğrencilerin çokluk ekleriyle ilgili 
yanlışlarının daha çok ekin fazladan kullanımından ya da tam tersine eksik kullanımından kaynaklandığı belirtilmiştir.

Yabancı dil olarak Türkçe öğrenenlerin C1 sınavı yazma becerisindeki dil bilgisi hatalarının seviyelere göre dağılımının incelendiği bu çalışmada hataların \%80'inin A1 seviyesinde, \%4,7'sinin A2 seviyesinde, \%13,5'inin B1 seviyesinde ve \%1,5'inin B2 seviyesinde olduğu tespit edilmiştir. A1 seviyesindeki dil bilgisi yapılarının kullanımında hata oranının belirgin bir şekilde yüksek olduğu görülmektedir. Bu durum A1 seviyesindeki dil bilgisi yapılarına daha fazla ağırlık verilmesi gerektiğini göstermektedir. Dil bilgisi, dört temel dil becerisinin gelişimine destek olan temel öğrenme alanlarından birini oluşturmaktadır. Türkçeyi yabancı dil olarak öğrenenlerin bulundukları seviyeye ait dil bilgisi konularını tam olarak öğrenmeksizin anlama ve anlatma becerilerinde Türkçeyi doğru bir şekilde kullanabilmeleri mümkün değildir. Dil bilgisi konularının anlatma becerileri olan konuşma ve yazma becerilerinde kullanılabilmesi anlama becerileri olan okuma ve dinleme becerilerinden daha zordur.

Yabancı dil olarak Türkçe öğretimi sürecinde öğrencilere yöneltilen soruların üst düzey becerileri ölçmesi gerekir (Ustabulut, 2020, s. 168). Yazma becerisi Bloom Taksonomisi;ne göre daha üst basamak becerilere işaret etmektedir. Türkçenin yabancı dil olarak öğretiminde süreç temelli öğretime yer verilmesi gerekmekte olup öğretim süreci içerisinde sarmal programlama yaklaşımı esas alınmalıdır. Öğretilmesi planlanan konularda tam öğrenmenin sağlanıp sağlanmadığı yazma etkinlikleriyle belirlenmeli ve geri bildirimler sunulmalıdır. Öğretimi gerçekleştirilmiş olan konuların unutulmaması ve pekiştirilmesi için yeni öğrenmeler içerisinde tekrar edilmesinde fayda bulunmaktadır. Özellikle öğrencilerin öğrenmekte zorlandıkları konular için ilgili konuya ait etkinliklerin artırılması, çeşitlendirilmesi, öğretim süresinin uzatılması ve öğrenmelerin tekrar edilmesi konunun tam anlamıyla öğrenilmesi açısından önem arz etmektedir.

\section{Kaynakça}

Açık, F. (2008). Türkiye'de yabancılara Türkçe öğretilirken karşılaşılan sorunlar ve çözüm önerileri [Konferans/Sempozyum Sunumu]. Uluslararası Türkçe Eğitimi ve Öğretimi Sempozyumu, KKTC.

Ak Başoğul, D., ve Can, F. S. (2014). Yabancı dil olarak Türkçe öğrenen Balkanlı ögrencilerin yazılı anlatımda yaptıkları hatalar üzerine tespitler. Dil ve Edebiyat Eğitimi Dergisi, 10, 100-119.

Atagül, Y. Y. ve Cevher, Ö. Y. (2015). Türkçenin yabancı dil olarak öğretiminde hâl eki sorunsalı (Sakarya Üniversitesi Örneği). TÜRÜK Uluslararası Dil, Edebiyat ve Halkbilimi Araştırmaları Dergisi, 3(5), 294-332.

Avrupa Konseyi / Modern Diller Bölümü. (2013). Diller için Avrupa ortak öneriler çerçevesi öğrenim, öğretim ve değerlendirme. https://www.telc.net/fileadmin/user_upload/Publikationen/Diller_iain_Avrupa_Ortak_one riler_AEeraevesi.pdf adresinden 1 Ekim 2020 tarihinde alınmıştır.

Banguoğlu, T. (1986). Türkçenin grameri. Ankara: Atatürk Kültür, Dil ve Tarih Yüksek Kurumu Yayınları. 
Barın, E. (2004). Yabancılara Türkçe öğretiminde ilkeler. Hacettepe Üniversitesi Türkiyat Araştırmaları, 1, 19-30.

Barın, E., Çobanoğlu, Ş., Ateş, Ş., Balcı, M. ve Özdemir, C. (Ed.). (2018). Yedi iklim Türkçe Al. Ankara: Başak Matbaacılık.

Barın, E., Çobanoğlu, Ş., Ateş, Ş., Balcı, M. ve Özdemir, C. (Ed.). (2018). Yedi iklim Türkçe A2. Ankara: Başak Matbaacılık.

Barın, E., Çobanoğlu, Ş., Ateş, Ş., Balcı, M. ve Özdemir, C. (Ed.). (2018). Yedi iklim Türkçe B1. Ankara: Başak Matbaacılık.

Barın, E., Çobanoğlu, Ş., Ateş, Ş., Balcı, M. ve Özdemir, C. (Ed.). (2018). Yedi iklim Türkçe B2. Ankara: Başak Matbaacılık.

Barın, E., Çobanoğlu, Ş., Ateş, Ş., Balcı, M. ve Özdemir, C. (Ed.). (2018). Yedi iklim Türkçe Cl. Ankara: Başak Matbaacılık.

Boylu, E. (2019). Yabancllara Türkçe ögretiminde ölçme değerlendirme uygulamaları ve standart oluşturma [Doktora tezi]. Çanakkale Onsekiz Mart Üniversitesi.

Candaş Karababa, Z. C. (2007). Yabancı dil olarak Türkçenin öğretimi ve karşılaşılan sorunlar. Ankara University, Journal of Faculty of Educational Sciences, 42(2). 265-277.

Çelik, M. E. (2019). Yazılı metinlerde ölçme ve değerlendirme. M. N. Kardaş ve R. Koç (Ed.), Türk dili I yazma eğitimi içinde (ss. 270-327). Ankara: Pegem Akademi Yayınları.

Demirel, Ö. (2014). Eğitimde program geliştirme kuramdan uygulamaya. Ankara: Pegem Akademi Yayınları.

Feng, S. and Powers, K. (2005). The short-and long-term effect of explicit grammar instruction on fifth graders' writing. Reading Improvement, 42(2), 67-72.

Göçer, A. (2019). Yazma eğitimi. Ankara: Pegem Akademi Yayınları.

Güneş, F. (2019). Türkçe ögretimi yaklaşımlar ve modeller. Ankara: Pegem Akademi Yayınları.

Güven, E. (2007). Yabancıların Türkçe ögrrenirken ad durum eklerinde yaptıkları hataların çözümlenmesi ve bu hataların giderilmesine yönelik öneriler [Yüksek lisans tezi]. Dokuz Eylül Üniversitesi.

İltar, L. (2018). Türkçenin yabancı dil olarak ögretiminde kullanılan ders kitaplarındaki okuma metinlerinin farklı değişkenler açısından değerlendirilmesi [Doktora tezi]. Gazi Üniversitesi.

İlter, B. G. (2014). Yabancı dil öğretiminde yazma becerisi nasıl geliştirilebilir? Dil Dergisi, $163,36-45$.

Kana, F. ve Erol S. (2019). Türkiye'de öğrenim gören Arap öğrencilerin Türkçe temel düzeyde yaşadığı dil bilgisi sorunları. Tarih Okulu Dergisi, 40, 549-559.

Kara, M. (2010). Gazi Üniversitesi TÖMER öğrencilerinin Türkçe öğrenirken karşılaştıkları sorunlar ve bunların çözümüne yönelik öneriler. Türk Eğitim Bilimleri Dergisi, 8(3), 661696.

Korkmaz, C. B. (2019). The evaluation of the writing skills of international students in terms of error analysis. International Online Journal of Educational Sciences, 11(3), 179-194. 
Şahin, E. Y. (2013). Yabancı dil olarak Türkçe öğrenen öğrencilerin yazılı anlatımlarındaki ek yanlışları. Tarih Okulu Dergisi, 6(15), 433-449.

Ustabulut, M. Y. (2020). Yabancı dil olarak Türkçe öğretiminde yansitıcı düşünme becerisi. İstanbul: Hiperyayın.

Yıldırım, A. ve Şimşek H. (2016). Sosyal bilimlerde nitel araştırma yöntemleri. Ankara: Seçkin Yayıncılık.

\section{Extended Summary}

Grammar is of significant importance in receptive and productive skills. It does not seem possible to reach the desired level of language proficiency in receptive and productive skills without mastering the grammar in the target language. While assessing the language learning progress, the learning objectives of the relevant level can be detected more clearly, especially in the writing skill, and thus more useful feedback can be provided there. Lack of grammar proficiency leads to communication problems, especially in the writing skill, compared to the other language skills. While grasping grammar rules in a reading or a listening text signifies lower competencies in accordance with the Bloom's Taxonomy, using newly-learned grammar rules in the novel contexts indicates higher level competencies. In this sense, it is more difficult to reach the proficiency level in using the grammar rules in the productive skills than comprehending the grammar rules in receptive skills. This gives rise to certain communication problems in productive skills mainly because of the grammar mistakes made. In this study, which aims at determining the grammar mistakes made by those who learn Turkish as a foreign language in the $\mathrm{C} 1$ exam, in the writing skill part, in accordance with their levels, a case study from qualitative research design patterns was employed. Document review was implemented in this study, and content analysis was used to analyze the data. The data of the study consists of the answers given to the writing questions in the $\mathrm{C} 1$ writing exam by 42 students studying at $\mathrm{C} 1$ level at Ankara Y1ldirım Beyazit University Language Education Application and Research Center in the 2018-2019 academic year. In deciding on the levels and classification of grammar subjects, the grammar rules specified in the Yedi Iklim Türkçe Ögretim Seti, which the students in the study group studied during the Turkish learning process were taken as basis. Within the scope of the research, in the writing exam conducted for 42 students at $\mathrm{C} 1$ level, the errors in grammar structures specified in the Yedi İklim Türkçe Ögretim Seti used by the students were examined according to their levels. After reviewing the written productions, it was found out that the students repeatedly made mistakes 301 times in 22 different grammar categories at A1 level, 18 times in 5 different grammar categories at A2 level, 51 times in 11 different grammar categories at B1 level and 6 times in 3 different grammar categories at B2 level. C1 level is specifically excluded from the scope of the study, since there is no learning objective related to any grammar structure at $\mathrm{C} 1$ level in the Yedi İklim Türkçe Ögretim Seti.

The grammatical mistakes at A1 level are as follows according to the number of repetitions: 78 times accusative case, 62 times noun phrase, 49 times [palatal] vowel 
harmony, 31 times dative case, 17 times plural suffix, 10 times possessive suffix, 10 times constructional suffixes (-1I), 7 times prepositional suffixes (-A göre), 7 times location case, 6 times ablative case, 3 times constructional suffix (-lIk), 3 times consonant affinity, 3 times adjective forming suffix of -ki, 3 times preposition (ile), 3 times present tense, 2 times [labial] vowel harmony, 2 times future tense, 1 time personal suffix, 1 imperative suffix, 1 time vowel drop, 1 time simple past tense, 1 time preposition group (-A kadar).

The grammatical mistakes in A2 level are as follows, according to the number of repetitions: 7 times present tense, 4 times verbal noun, 4 times abilitative verb form, 2 times preposition group (-mAk için), 1 time verbal adverb (-ArAk), respectively.

The grammatical mistakes at the B1 level are as follows, according to the number of repetitions: 13 times causative voice, 12 times passive voice, 8 times adjectival verb (-DIk), 5 times conditional, 4 times adjectival verb (-An), 3 times adjectival verb (-mIş), 2 times past progressive tense, 1 time reciprocal suffix, 1 time necessitative mood (gerekli), 1 time necessitative mood (-mAlI), 1 time subjunctive mood.

The grammatical mistakes in B2 level are as follows according to the number of repetitions: 4 times compound verbs, 1 time preposition group (-mAsInA rağmen), 1 time preposition group (-DIğI için).

When all levels are taken into consideration, it is seen that the most frequently recurring five grammatical mistakes are at A1 level. The most frequently repeated five grammatical mistakes regarded as an error is respectively concluded to be the accusative case suffix with $20.7 \%$, the noun phrase with $16.4 \%$, the palatal vowel harmony with $13 \%$, the dative case suffix with $8.2 \%$ and the plural suffix with $4.5 \%$. In this study, in which the distribution of grammar mistakes in the $\mathrm{C} 1$ exam writing skill of those who learn Turkish as a foreign language was examined, $80 \%$ of the errors were found to be at A1 level, $4.7 \%$ at A2 level, 13.5\% at B1 level, and 1.5\% at B2 level. It is seen that the rate of errors committed is significantly high in the use of A1-level grammar structures. This shows that more emphasis should be placed on grammar structures at A1 level. Whether mastery has been achieved in the learning objectives or not should be determined through the writing activities, and feedback should be provided. It would be beneficial to repeat the former subjects in the following new units for better reinforcement. Especially for the subjects that students have difficulty in learning, increasing the number and diversity of the activities related to the relevant subject, extending the teaching period and repeating the learning objectives would prove to be significant in order to fully grasp the subjects. 